\title{
To be a cyborg: towards the dialogue between science and religion
}

\author{
Maksim Maidansky ${ }^{1,{ }^{*}}$, Irina Maidanskaya ${ }^{1}$, and Olga Dekhnich ${ }^{1}$ \\ ${ }^{1}$ Belgorod National Research University, 308015, Belgorod, Russia
}

\begin{abstract}
The paper deals with the consequences of technological transformation of the biological nature of human beings. How will our religious and scientific worldview change? What arguments for and against human cyborgization do naturalists and engineers, philosophers and futurologists propose? Answers to these questions can be decisive in determining the future of humanity. The Russian philosophers-cosmists were the first to put their minds to this problem; nowadays, this dialogue is conducted on the border between science and religion. The image of cyborg is a kind of testing ground for discussing philosophical concepts about human nature and interaction of man with the external world, about the limits of historical development and the meaning of human existence.
\end{abstract}

\section{Introduction}

At the end of the 19th century, the Russian Cosmist Nikolay Fedorov first spoke about the need to enhance human body with the help of science (and even to resurrect all "fathers" at some future time!). In the next century, this idea was picked up by the pioneer of practical cosmonautics Konstantin Tsiolkovsky, by his pupil Alexander Chizhevsky and a number of other thinkers. To develop and promote the idea of space travel, they created "an informal, vibrant, and international network that existed outside the parameters of the 'traditional' and elite scientific world" [1].

Cosmism became, perhaps, the most distinctive branch of Russian philosophy and its "face" in the West. Last year, two collections were published, in English and German $[2,3]$. They include the classic works of Russian Cosmists, mainly in new translations.

The reception of Russian cosmism was reinforced manifold by the successes of practical cosmonautics in the Soviet Union. "Once dismissed and derided, Cosmist ideas are now regarded as a main tendency in Russian culture and thought," as the American researcher George Young maintains [4].

A new look at the role of mankind in the evolution of the Universe is at the heart of the Cosmists' worldview. All of them are convinced that humanity should carry out a certain cosmic mission. In his "Cosmology of Mind", Evald Ilyenkov even suggested that the "thinking mind" is destined to save Mother Nature from the "heat death".

Man is able to release and accumulate huge amounts of energy. In this sense, human activity is a non-entropic factor of evolution. It transforms not only the external nature, but

\footnotetext{
*Corresponding author: maxmaid@,rambler.ru
} 
the human body itself. The structure and appearance of the human body are changed inevitably and irreversibly. This is the problem which our work is devoted to.

\section{Cyberoptimists vs. bioconservatives}

We would not discuss here the far prospect of emergence of "the most perfect type of organism living in the ether and feeding directly on solar energy" [5]. Still, in our age of high technology, a radical transformation of the body is the order of the very near future.

The representatives of various directions of transhumanism are the most optimistic on this problem. Their leaders, scientists and inventors of world renown - M. Minsky, R. Kurzweil, R. Penrose, H. Ishiguro - not only theoretically construct technotronic models of man, but also make direct practical experiments on implanting microchips, creating androids, etc. On this basis, a special type of worldview is formed, which, according to their plan, will turn into a dominant, if not a universal one.

Cyberoptimists are opposed by the party of bioconservatives. Their leaders F. Fukuyama, in the West, and V.A. Kutyrjov, in Russia, - express deep concern about the prospect of "cyborgization" or "hybridization" of homo sapiens. They are anxious not only about the "generic" biological appearance of man, but also for our social structure.

Thus, Jason Scott Robert and Françoise Baylis argue that "the creation of novel beings that are part human and part nonhuman animal is sufficiently threatening to the social order that for many this is sufficient reason to prohibit any crossing of species boundaries involving human beings" [6].

This kind of anxiety is largely due to the image of cyborg in science fiction literature and popular culture, as a creature which brings new technological and humanitarian risks, possibility of various negative effects of new technologies, etc.

The term "cyborg" is acronym for "Cybernetic organism". It was coined in 1960 by Manfred Clynes and Nathan S. Kline as a means of technological adaptation of the human body to an unfavorable environment. Tsiolkovsky also thought a lot about the same matters; in the last years of his life, he wrote a special work on this subject, "The Animal of the Cosmos".

Cyborg is a human body, enhanced with using various technical devices. In this sense, modern technologies of prosthetics and implantation (from artificial teeth to pacemakers) are presented as the first step towards cyborgizing the human body.

For human sciences, the image of cyborg is a kind of testing ground for discussing philosophical concepts about human nature, the relationship between the artificial and the natural in human being, the problems of human interaction with the external nature, the boundaries of historical development and even the meaning human existence.

Some cognitive scientists consider all people to be "natural-born cyborgs" (Andy Clark), because people live and act according to artificial programs that are not genetically "written" in their organisms. After all, is it really important, are tablet computers and cell phones built directly into the body, or do we carry them with us in bags and pockets? From the point of view of functioning of these devices, the method of their connection with the human body does not matter.

Anyone who, sitting at a computer, expands and strengthens his memory, horizons, computational abilities, etc., with the help of computer programs, has already become a cyborg. In this case, what new could the integration of electronic computing equipment directly inside the human body bring us? This can hardly be called a completely new stage of human evolution. Rather, it will only be a continuation and development of the evolutionary line along which the humankind has been successfully moving for a long time.

According to the American biologist and "cyberfeminist" Donna Haraway, modern technology can not be regarded as a continuation of the body. Rather, our bodies are living 
appendages of the technosphere. As Haraway calls us, not without irony, it's time to honestly declare yourself a cyborg. "We find ourselves to be cyborgs, hybrids, mosaics, chimeras. Biological organisms have become biotic systems, communications devices like others. There is no fundamental, ontological separation in our formal knowledge of machine and organism, of technical and organic [7]. Late-twentieth-century machines have made thoroughly ambiguous the difference between natural and artificial, mind and body, self-developing and externally designed, and many other distinctions that used to apply to organisms and machines. Our machines are disturbingly lively, and we ourselves frighteningly inert" [8].

According to Haraway's forecast, these processes will lead to erasure of gender differences, to disappearance of the boundaries between the human-animal and the humanmachine, and even between soul and body. At the same time, the problem of gender inequality will be finally resolved.

\section{Cyborg in religious consciousness}

The role of religion, of various religious denominations in the modern technological society is of particular interest to us, since their representatives occupy a place in the first row of fighters against changing the world by technology.

As might be expected, religious parties mostly uphold bioconservative views, advocating the immutability of the physical constitution of man. Religions in general, by their very nature, tend to resist to innovations; they seek the golden age in the past and predict the Judgment Day in the future. Cyborgization of humanity fits well into this kind of apocalyptic picture of the future. However, upon closer examination, it turns out that the situation is much more complicated.

In this connection, a research by sociologist Brenda Brasher is of interest. It deals with the attitude of religious communities to the creation of new species. Brasher's book Give Me That Online Religion shows that traditional, institutionalized religions, as a rule, refuse to rethink their teachings and symbols in the light of new historical circumstances and changes in society, dictated by modern technologies. And cyborgs, these human machines, more than anything else, embody the threat of dehumanizing the world.

The image of cyborg causes existential feelings of disharmony and insecurity of a person's position in the world. Humanity is approaching a turning point in its history, when human nature itself can change and, as a result, all social relations, from family to political would change, too. The symbol of these changes is the cyborg, by virtue of its (or his / her) inherent duality of the natural and the artificial, the living and the inanimate, the human and the non-human.

Brasher explains this phenomenon as follows: "Presuming an inseparable connection between the self and other, the cyborg offers a metaphoric platform upon which complex human identities might be developed. ... The cyborg as a root metaphor for contemporary human identity offers the capacity to encourage a responsible awareness of and interaction with the material world" [9].

Brasher sees the positive role of religion in the constant reminder that a person must control the volume of his / her contacts with technologies that are fraught with loss of personality, with dissolution in high-tech environments.

Brasher's research, however, does not fully take into account the flexibility of religious consciousness, its ability to change in response to new, including anthropogenic, challenges. It would be wrong to think that religion is not able to "digest" the concept of cyborg at all, and can only reject it again and again. The history of religion demonstrates a rich set of hybrids of the human and the divine, and Christianity has created the most impressive hybrid - the idea of the God-man Jesus Christ, theologically interpreted in the 
concept of Holy Trinity. Reflections on the relationship between God and man, as the earthly "image of God", can be understood as a mythological anticipation of the future of humanity and a religious prototype of the scientific concept of cyborg.

On the one hand, human beings are part of the natural world, and their physical bodies obey all the laws of nature; on the other hand, the divine essence is embodied in man, he bears the image of God, so he has the opportunity to enter into direct and immediate communication with the Creator and to be a creator himself. Man creates new artifacts, norms of culture and technology, works of art and scientific concepts. According to the biblical notions, man stands with one foot in the heavenly world, and the other in the earthly world - but the cyborg does the same, with the difference that its "second nature" is technical, not biological. From a scientific point of view, this difference is not so significant. In the eyes of science (if to speak about science as such, and not about individual scholars combining scientific views with religious ones), the heavenly world is the same invention of the human mind as technology.

\section{Conclusion}

In fact, it is not necessary to be a Christian in order to see the fundamental duality, the "hybridity" of human nature. Being an inhabitant of the physical, natural world, man, at the same time, discovers the ability to create his own artificial world. Religious people see this ability as "the divine spark", philosophers use the term "transcendence", and the image of cyborg only brings these traditional ideas to their logical limit, sharpening all the contradictions arising from the recognition of our ability to creating a new world, to conscious innovation. Those who recognize this creative ability as a supreme value and make it a measure of historical progress, must take the concept of cyborg seriously.

On the part of Maksim A. Maidansky, this work is supported by the Russian Science Foundation under grant no. 19-18-00100.

\section{References}

1. A.A. Siddiqi, The Red Rockets' Glare: Spaceflight and the Soviet Imagination, 18571957, 12 (Cambridge University Press, 2010)

2. Kosmismus (Matthes \& Seitz, Berlin, 2018)

3. Russian Cosmism (MA, EFlux-MIT Press, Cambridge, 2018)

4. G.M. Young, The Russian Cosmists: The Esoteric Futurism of Nikolai Fedorov and His Followers, 4 (Oxford University Press, Oxford, 2012)

5. K.E. Tsiolkovsky, Essays on the Universe, 205 (Zolotaja alleja, Kaluga, 2001)

6. J.S. Robert, F. Baylis, J. Amer, Of Bioethics, 3, 10 (2003)

7. D. Haraway, The Haraway Reader, 35 (Routledge, London, New York, 2004)

8. D. Haraway, The Haraway Reader, 11(Routledge, London, New York, 2004)

9. B.E. Brasher, Give Me That Online Religion, 825 (Rutgers University Press, New Brunswick, 2004) 